\title{
Interrogating the Adoption of Quality Assurance Parameters in the Management of Private Basic Schools in Six Local Government Areas, Kano
}

\author{
Fabian Ndidi Nwaugo Mansur Ali Garba \\ Department of History, Federal College of Education, Kano - Nigeria
}

\begin{abstract}
This paper interrogates the adoption of quality assurance in private basic schools in Kano state. To achieve this task, six (6) local government areas, selected from the three (3) senatorial zones of Kano Central, Kano North and Kano South were used. On completion of the fieldwork which lasted from June to September, four (4) months, through the survey design approach, data was analysed by the use of descriptive statistical analysis. In this case percentage score was considered appropriate because the responses were structured following a strongly agree, agree, disagree and strongly disagree considered version of Likerts Scale. The findings from fieldwork showed that first there was a uneven distribution of private schools across the three Senatorial zones as Gwale has the highest number of 118 (44.02\%), Fagge 97 (36.19\%), Gezawa 22 (8.20\%), Dawaki 14(5.22\%), Wudil 4(1.49\%) and Rogo 13 (4.85\%). The differential was accounted for by population growth and immigrants settlement. Secondly, most private actors in the education sector were drawn into the industry with the urge to maximize returns on investment. It also showed that the environment under which most of they operates are not conducive for teaching and learning. The research also found out that supervision of these private schools are not adequate as emphasis was on collecting all manner of levies and gratification. The paper recommended that a data bank for all the private schools operating in Nigeria which this present research initiated should be done in other parts of the federation. Also multiple supervisory agencies should be trimmed to one for improved efficiency with offices established in all the local government areas. Extant laws on quality standard should not be compromised henceforth and schools found wanting must be closed down permanently. The paper also recommended that the Ministry of Education and a taskforce should clamp down on private schools established very close to Hotels and brothels. This would help to vestor sanity in the education system. Finally, government should intervene in the area of instructional materials to these schools and control the fees they should collect. On the balance sheet, the paper concludes without reservation that private basic schools in Kano have abandoned their complimentary function of providing quality education to the Nigerian children.
\end{abstract}

Keywords: Interrogating, Adoption, Quality Assurance, Parameters, Management.

DOI: $10.7176 / \mathrm{JEP} / 10-3-18$

\subsection{Introduction:}

The establishment of private schools in Nigeria has a long historical antecedent. According to Fafunwa (1974), Odeleye and Oyelami (2012), it was first started by the missionaries in the $19^{\text {th }}$ century essentially as an instrument of evangelization. However, statistics is not available to tell us how many of the private schools existed at that time.

The establishment of private schools in Nigeria gained more currency in the 1990s as a result of an awesome increase in the number of children that desired to be educated on basic literacy. When the Universal Basic Education (UBE) was conceived, it was estimated that about 1.12 million pupils in Nigeria will be registered, at a ratio of 1.40 and about 28,000 will be required to cater for the number registered. However, the figures of primary school enrolment for the scheme indicated that there were about 21 million pupils enrolled in Nigeria schools in 1999/2000 academic session. The enrolment figure in Kano state was 1,288,997 (Baikie, 2002:3) and during the same period, the total projected enrolment figure for 2000/2001 was given as 25,250,499, about 4.4 million more than the 1999/2000 figure (Baikie, 2002:25). This expansion in the enrolment figures of pupils in the primary and secondary schools had critical implication for the industry. There were more demands in the number of classrooms, instructional materials, furniture and equipment. Regrettably, the various level of government found it difficult to contend with and cater adequately for these demands. Thus, private participation in the ownership, control and management of schools became a necessity. Kano state being the commercial nexus of Northern Nigeria, its urban character and the most populous city in Nigeria, with a striking population of 9,401,288 became a fertile ground and vineyard for the predators to establish private schools in the guise of assisting the government to provide basic literacy to the teeming Nigeria's children.

\subsubsection{Clarification of Keywords:}

The keywords used in this paper need to be situated in its textual context to avoid ambiguity.

- Adoption: Adoption in the context of this paper would be taken to mean the willingness of the proprietors to implement government's spelt out parameters that would ensure quality delivery in the management of 
private basic schools in Kano state.

- Interrogating: This simply means asking someone a lot of questions in order to get information. To this extent, the proprietors of private basic schools in Kano State are being interrogated in the light of public outcry with nefarious activities which is antithetical to acceptable standards.

- Management: Management of a school is an important aspect of the entire education system. In the context of this paper, it represents how efficient proprietors of private basic schools have been able to coordinate the activities of the school for a better educational experience to the pupils and students.

- Quality Assurance in Education: Quality in education is all encompassing, it covers a wide spectrum of activities carried out in the sector such as teaching, scholarship, staffing, buildings, facilities, equipment, services to the community and academic environment (UNESCO, 1998). The growing concern about quality in education was essentially as a result of massification of education and the desire by organizations and individuals to exploit the leverage provided by the government for private participation in the establishment and management of private institutions. To this extent, these private basic schools have been turned into vineyards for profit maximization through exorbitant school fees and other levies. Also concern about quality revolves around learning environment, poor classroom, outrageous number of pupils per class, lack of library facilities, and inadequate infrastructure.

\subsubsection{Efforts towards Promoting Quality in the Education Sector}

Government of Nigeria had put in place a number of measured to enhance quality in education throughout the country, including Kano State. In 1985, the Federal Government Promulgated Decree No. 16 on the minimum standard for primary and secondary schools nationwide. The Decree strives to achieve the following:

a) Provide guidelines on general and specific principles of inspection and monitoring of schools;

b) Provide tools for evaluating the efficiency of school management;

c) Guide proprietors in providing funds for the schools;

d) Use the guide for accrediting the schools;

For the effective implementation of the guidelines for the basic schools, the National Council of Education (NCE) and the Joint Consultative Council on Education (JCCE agreed to put in place a sub-committee in 1988 to streamline the guidelines. In 2001 the Committee was reconstituted with membership drawn from the six geopolitical ones to synthesize and harmonize their experiences and some other relevant departments and parastatals of the Federal Ministry of Education.

The outcome of their deliberation culminated in the formulation of 15-item guidelines on minimum standards for the basic schools all over Nigeria. These items include the following:

i) The minimum number of pupils per class,

ii) Pupil - teacher ratio,

iii) Minimum number of weeks per year,

iv) Teaching qualification,

v) Qualification for principals/head-teachers

vi) Records,

vii) Administrative block

viii) Fencing

ix) Physical structures,

x) Special buildings (Maduewesi, 2005:204).

Each item is specified quantitatively under "mandatory", "ideal" and "optional stages" of the institution at the levels of pre-primary, primary and secondary. All essential structures and materials that must be in place at least for the first 5 years of existence are labeled as mandatory (FME, 2002) such as library, good physical structure, basic health scheme, teacher pupil ratio of 1:35 and for JSS or upper basic 1:40.

However, observation during the fieldwork revealed a negative experience of poor physical structure, lack or inadequate library facilities, lack of infrastructure, no health case scheme, poor location and over bloated classes (Fieldwork, 2017).

\subsubsection{Private Basic School}

Essentially, private basic schools are owned, controlled and managed by individuals, groups, organizations and religious bodies. The education they provide is a 9-year teaching/learning programme comprising of 6 years of primary education and 3 years of Junior Secondary Education. It equally include adult and non-formal education run by non-governmental organization, individuals and religious bodies (NPE, 2004:7). Fundamentally, the six years of lower basic education is the bedrock of further teaching and learning programme for the development of the whole being of the children. The National Policy on Education describes it as the "Key to the successor or failure of the whole education system". (NPE, 2004:8).

\subsubsection{Subjects to be taught at the Lower Basic Education}

The subjects include:

1) Language of the environment 
2) English

3) French

4) Arabic

5) Mathematics

6) Science

7) Physical and Health Education

8) Religious Knowledge

9) Agriculture/Home Economics

10) Social Studies/Citizenship Education

11) Civic Education

12) Cultural and Creative Arts (Drawing, Handicraft, Music and Cultural Activities)

13) Computer Education. (NPE, 2004:9).

\subsubsection{Subject Taught at the Upper Basic Education}

1) Agricultural Science

2) Arabic

3) Basic Science

4) Basic Technology

5) Business Studies

6) Civic Education

7) Creative Arts

8) English Language

9) French Language

10) Hausa Language

11) Literature in English

12) Mathematics

13) Physical and Health Education

14) Religious Studies

15) Social Studies

\subsection{Statement of the Problem}

Private Basic Schools all over Nigeria are established to supplement government efforts in the provision of quality education to pupils and students at the lower basic and upper categories. However, there had been recent outcry by members of the public and other major stakeholders in the education sector on the alarming decay in the operations of most of these private schools. Some school of thought have argued that significant number of these schools disregard established quality assurance standard prescribed by the government and then collect exorbitant schools fees and other unnecessary dues without giving attention to facilities and materials that would promote teaching and learning. Moreso, some of them operate without registration by the appropriate government agencies, thereby denying the state substantial amount of revenue. On the other hand, the proprietors of these schools believe that they have not deviated from the provision of quality education to the Nigerian citizens.

This paper would interrogate the extent of quality assurance compliance by the proprietors of private schools in Kano state.

\subsection{The Aim and Objectives}

The aim of the research is essentially to interrogate the extent of quality assurance compliance of private schools (Lower Basic and Upper Basic) in Kano State. Thus, the specific objectives of the study include the following:

1) To determine the spatial distribution of private schools in Kano

2) To determine the factors that encourage private participation in the establishment of schools

3) To determine whether the environment under which private schools operate is conducive for teaching and learning

4) To determine whether private schools in Kano are regularly supervised by the appropriate agencies for quality control.

\subsection{Research Questions}

1) What is the demographic distribution of private schools in the areas of study?

2) What is the most important responsible for the establishment of private schools in Kano State?

3) Is the learning environment of private schools in Kano State conducive for teaching and learning?

4) Are private schools in Kano state regularly supervised for quality control? 


\subsection{Literature Review}

The National Policy on Education (2004) acknowledged the fact education is a veritable instrument to achieve national growth and sustainable development. However, with the escalating increase in the demand for education and the glaring inability of the government at all levels to cope with the demands, private ownership of schools was approved by the Federal Government. The performance of these private schools has therefore, elicited scholarly attention afterwards.

Baikie (2002) citing the statistics provided by the National Primary Education Commission illustrates the geometric growth of private schools from 1996 when it witnessed an upsurge. He observed that Lagos had the highest number of private schools, 821 with an enrolment figure of 282,089 pupils and 13,366 teachers. Jigawa had the least figure of 755 pupils. Baikie argues that the government should show more interest in private schools and offer them incentives and other forms of support

Egwa (2006:21) submits that the provision of uniform access to quality basic education presents a big challenge to the sector in view of economic, cultural, urban-rural dichotomy, public-private schools and other disparities across the country. These disparities have implication for provision of infrastructure, instructional materials, supervision and monitoring of learning achievements. He concludes that the children in our schools need to be guaranteed quality education in learning environment that results in high learning outcomes.

Ehindaro (2004) delineates four major indices of quality assurance which include the learner, teachers, teaching-learning process with emphasis on the structure of the curriculum and leaning environment and flow of operational fund.

Maduewesi (2005:203-204) observes that in 1985, the Federal Government promulgated Decree No. 16 on the minimum standard for primary and secondary education in Nigeria. The aims of the Decree are; provide guidelines on general and specific principals of inspection and monitoring of schools; provide tools for evaluating the efficiency of schools management. She identifies 15 items guideline on minimum standard for schools nationwide. These items include the minimum number of weeks per year, teaching qualification, qualification for principals/head-teachers, records, administrative block, kitchen and dining hall, staff quarters, fencing and physical structures.

Olagboye (1997) sees quality control as a mechanism put in place to maintain the degree of excellence of a product or service. In the context of education, it implies the arrangement by which education system ensures that service it delivers or intends to deliver serve the purpose for which it is intended. Its major area of emphasis is on the means by which the service the educational system provides remains relevant and appropriate to the needs of the society.

In their own submission Thomas (1991), Yoloye (1996), Fadipe (1999), sees quality assurance as the degree on ability with which an educational system conforms to the established standard and appropriateness of the inputs available for the delivery of the system.

Omede (2015), examines some issues that matters in private participation in education. Some of the challenges that hinders the effectiveness of private education institutions in Nigerian in providing quality and functional education include; profit making, he listed some of the reasons that propel individuals, groups and even religious bodies to establish schools as profit motivation, memorialize their departed relatives or immortalize their names, service to humanity, investment, social security against retirement and as a means of providing employment to numerous job seekers. Omede identifies the following issues to be addressed in order to improve the performance of private schools. They include; exorbitant fees and regular upward of fees, proliferation of sub-standard institutions, promotion of class consciousness and distinction, use of unqualified teachers and administrative staff, inadequate provision of infrastructural facilities and examination malpractice.

Agi (2013) outlines some of the essential features of private schools in Nigeria today as including; financed privately, managed and run privately, operate in environment less the standard of public schools, monitoring/evaluation system largely unknown, ready platform for 'miracle' centres, limited/non-availability of facilities, eg. Laboratories, quality assurance measures largely undisclosed and government recognition largely unknown for many private schools.

\subsection{Methodology}

The research adopted the survey design method and observation. Structured questionnaire of open and closed ended was used to solicit for information from respondents. The research instrument was validated by experts from the Directorate of Research and Educational Services of Federal College of Education, Kano. A pre-test of each of the research item in the questionnaire gave a Cronbach Alpha value of 0.82 rendering the research instrument as reliable.

The distribution of the questionnaire was preceded by radio announcement and facilitation visits to sensitize respondents on the importance of the exercise. Afterwards, the research instrument was self-administered and collected on the spotwith the help of research field officers both staff and students from Federal College of Education, Kano. The population involved 468 respondents comprising of proprietors (268), parents (100) and 
staff from the Department of Private School (50). A simple random sampling was used to select 200 respondents for the study. The exercise lasted from June to September, 2017 (4 months).

The data collected from the field was analyzed using the descriptive statistical approach. Percentage score was considered appropriate for this study because responses were structured following a condensed version of Likert's Scale. Strongly agree, agree, disagree and strongly disagree.

\subsection{Results}

Research Question 1: What is the demographic distribution of private schools (Basic and Upper Basic) in the survey area?

The distribution of private schools in the six local government areas chosen across the three (3) senatorial zones of Kano Central, Kano North and Kano South showed that Gwale has 118 private schools, representing 44.08 percent, Fagge follow with 97 schools, representing 36.19 percent, Gezawa has 22 schools, representing 8.20 percent, Dawaki 14 schools, representing 5.22 percent; Wudil has 4 representing 1.49 percent; while Rogo has 13 representing 4.85 percent.

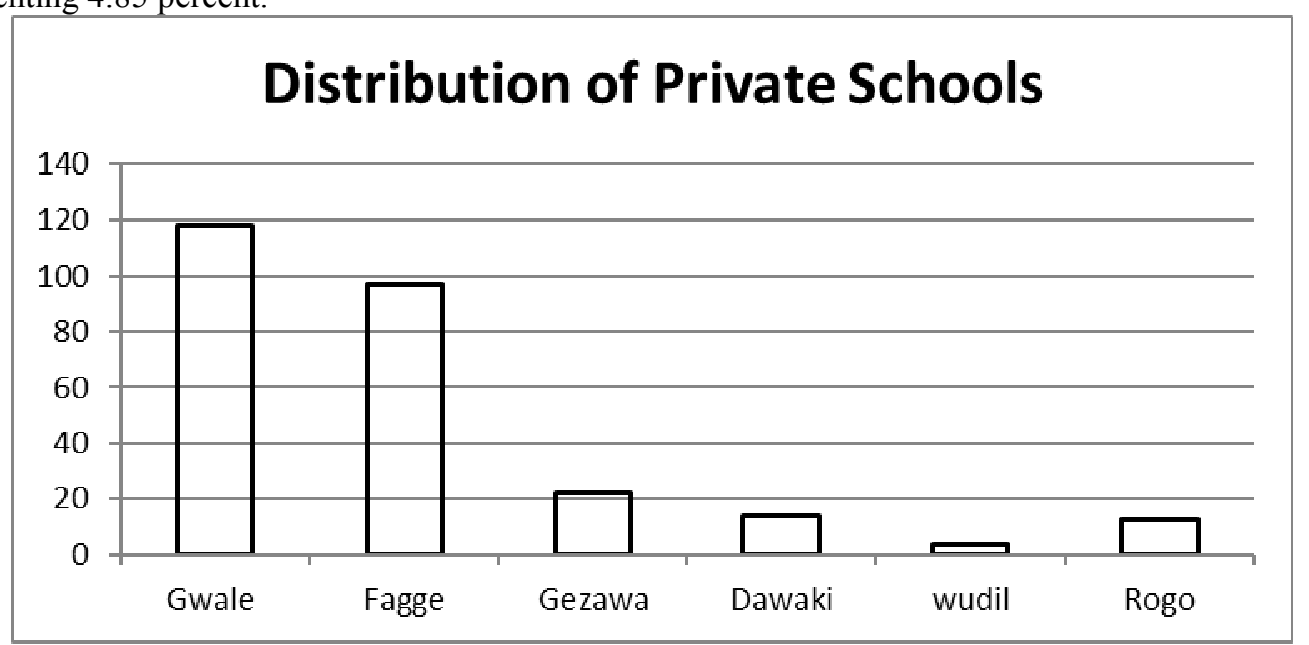

Figure 1: Distribution of Private Schools in the Survey Areas as shown in research question No. 1.

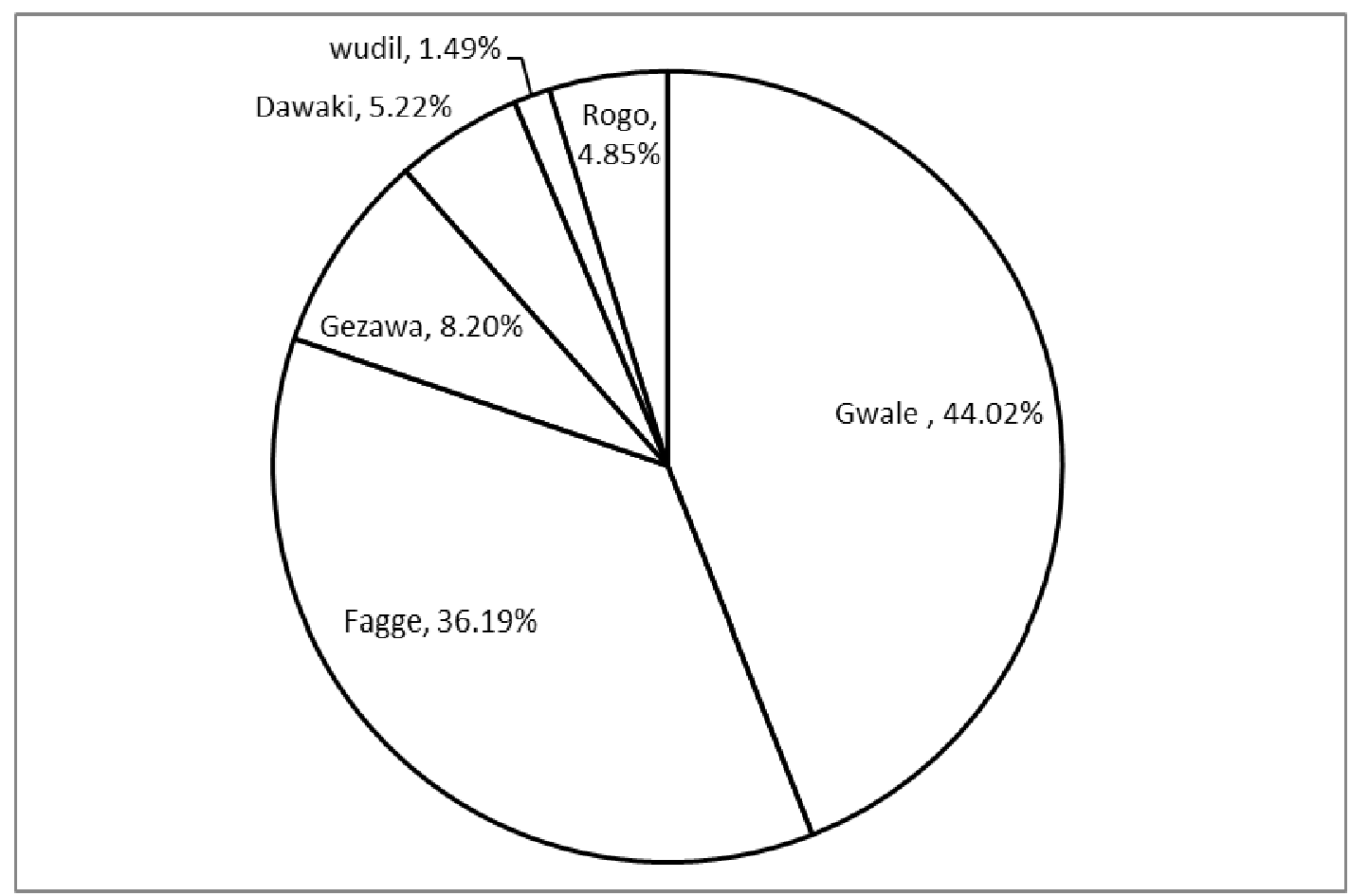

Figure 2:Percentage Distribution of Private Basic Schools in the Survey Areas:

Research Question 2: What is the most important factor responsibility for the establishment of private basic schools in Kano State? 
Table 1: Distribution of Responses According to Research Question 2:

\begin{tabular}{|l|l|c|c|c|c|c|}
\hline No. & \multicolumn{1}{|c|}{ Question } & $\begin{array}{c}\text { Strongly } \\
\text { Agree }\end{array}$ & Agree & Disagree & $\begin{array}{l}\text { Strongly } \\
\text { Disagree }\end{array}$ & Total \\
\hline 1 & $\begin{array}{l}\text { The most important reason that motivate } \\
\text { individuals to establish private basic school is } \\
\text { the need to make profit }\end{array}$ & 20 & 16 & 9 & 5 & 50 \\
\hline 2 & $\begin{array}{l}\text { People establish private basic schools for the } \\
\text { memorization/ immortalization of their } \\
\text { deceased ones }\end{array}$ & 18 & 18 & 0 & 4 & 40 \\
\hline 3 & $\begin{array}{l}\text { Individuals established private basic schools } \\
\text { for the sake of humanity }\end{array}$ & 15 & 12 & 3 & 0 & 30 \\
\hline 4 & People see it as an investment opportunity & 21 & 18 & 6 & 0 & 45 \\
\hline 5 & As means of providing job opportunities & 87 & 74 & 26 & 13 & 200 \\
\hline
\end{tabular}

Table 2:Distribution of Frequency According to Responses

\begin{tabular}{|l|c|c|}
\hline \multicolumn{1}{|c|}{ Responses } & Frequency & Percentage \\
\hline Strongly agree & 87 & $43.5 \%$ \\
\hline Agree & 74 & $37 \%$ \\
\hline Disagree & 26 & $13 \%$ \\
\hline Strongly disagree & 13 & $6.5 \%$ \\
\hline
\end{tabular}

Table 1.2 depicts that 43.5 percent strongly agreed that it was the need to make profit that motivate individuals and groups to establish private basic schools, while 37 percent of the respondents also affirmed, while 13 percent and 6.5 percent disagreed and strongly disagreed respectively. This analysis was in tandem with the observation of a popular Nigerian Television Authority (NTA) programme, 'Good Morning Nigeria' where the deplorable conditions of some private basic schools were brought to the fore. What actually mattered to the owners of such schools was the imposition of arbitrary school fees and other levies with less regard to standard and quality control.

Verification of Findings according to Research Question 3:

Research Question 3: Is the environment of Private Schools in Kano State Conducive for Teaching and Learning?

The respondents for this research question were drawn from parents and staff of the Department of Private Schools in Kano State Ministry of Education. This was essentially to eliminate distortion of facts which could have resulted from the participation of the proprietors of private schools in the survey areas.

Table 3: Distribution of Responses According to Research Question No. 3

\begin{tabular}{|c|c|c|c|c|c|c|}
\hline No. & Question & $\begin{array}{l}\text { Strongly } \\
\text { Agree }\end{array}$ & Agree & Disagree & $\begin{array}{l}\text { Strongly } \\
\text { Disagree }\end{array}$ & Total \\
\hline 1 & $\begin{array}{l}\text { There are good libraries where your children } \\
\text { receive instructions }\end{array}$ & 0 & 5 & 10 & 15 & 30 \\
\hline 2 & $\begin{array}{l}\text { The health care scheme in the private school } \\
\text { your children attend is adequate }\end{array}$ & 3 & 3 & 19 & 15 & 40 \\
\hline 3 & $\begin{array}{l}\text { The location of the private school your } \\
\text { children attend is satisfactory }\end{array}$ & 2 & 1 & 7 & 10 & 20 \\
\hline 4 & $\begin{array}{l}\text { The seats in the classroom are good enough } \\
\text { for the number of pupils in a class }\end{array}$ & 6 & 8 & 11 & 10 & 35 \\
\hline 5 & $\begin{array}{l}\text { There is a spacious play ground in the school } \\
\text { that your wards attend }\end{array}$ & 1 & 2 & 5 & 17 & 25 \\
\hline & Total & 12 & 19 & 52 & 67 & 150 \\
\hline
\end{tabular}

Table 4: Distribution of Frequency According to Responses

\begin{tabular}{|l|c|c|}
\hline \multicolumn{1}{|c|}{ Responses } & Frequency & Percentage \\
\hline Strongly agree & 12 & $8 \%$ \\
\hline Agree & 19 & $12.66 \%$ \\
\hline Disagree & 52 & $34.66 \%$ \\
\hline Strongly disagree & 67 & $44.66 \%$ \\
\hline
\end{tabular}

Following table 2.3, it was glaring that out of 150 responses, 12 strongly agreed that environment of private schools in the survey areas are conducive for teaching and learning, representing $8 \%, 19$ responses agreed $(12.66 \%)$ while 52 responses disagreed making a percentage of $34.66 \%$, while 67 responses strongly disagreed, representing 44.66 percent. The import of this meant that most of the respondents frowned on the environment of 
the private basic schools and its negative effect on scholarship.

Hetherington and Parke (1999) as cited in Tanda (2016:58) were very positive on the role of the environment in the development of pupils intellectual abilities. A conducive environment encourages a child to become self-reliant, and express his or her curiosity. Other environmental factors that impedes pupils intellectual and cognitive development at a formative stage include the absence of pipe born water in the school, lack of good playing ground, lack of library, poor school infrastructure and small classroom space. Regrettably, most of the private basic schools in the survey area are characterized by poor environment with its concomitant negative effect on pupils intellectual and cognitive development.

Research Question 4: Are Private Schools in Kano Regularly Supervised for Quality Control?

Table 5: Distribution of Responses According to Research Question No. 4

\begin{tabular}{|c|c|c|c|c|c|c|}
\hline No. & Question & $\begin{array}{l}\text { Strongly } \\
\text { Agree }\end{array}$ & Agree & Disagree & $\begin{array}{l}\text { Strongly } \\
\text { Disagree }\end{array}$ & Total \\
\hline 1 & $\begin{array}{l}\text { Private basic schools are regularly } \\
\text { supervised }\end{array}$ & 5 & 7 & 10 & 18 & 40 \\
\hline 2 & $\begin{array}{l}\text { Supervision of private basic schools are } \\
\text { driven by money collection }\end{array}$ & 5 & 8 & 20 & 17 & 50 \\
\hline 3 & $\begin{array}{l}\text { Supervision of private basic schools are } \\
\text { carried out by one agency }\end{array}$ & 4 & 1 & 10 & 15 & 30 \\
\hline 4 & $\begin{array}{l}\text { Supervision was intended to promote } \\
\text { standard and quality control }\end{array}$ & 9 & 11 & 13 & 12 & 45 \\
\hline 5 & $\begin{array}{l}\text { Supervision of private basic schools covers } \\
\text { all the schools }\end{array}$ & 4 & 4 & 8 & 19 & 35 \\
\hline & Total & 27 & 31 & 61 & 81 & 200 \\
\hline
\end{tabular}

Table 6: Distribution of Frequency According to Responses

\begin{tabular}{|l|c|c|}
\hline \multicolumn{1}{|c|}{ Responses } & Frequency & Percentage \\
\hline Strongly agree & 27 & $13.5 \%$ \\
\hline Agree & 31 & $15.5 \%$ \\
\hline Disagree & 61 & $30.5 \%$ \\
\hline Strongly disagree & 81 & $40.5 \%$ \\
\hline
\end{tabular}

Following table 2.4, it can be seen that out of 200 responses, 27 responses strongly agreed that private basic schools are regularly supervised for standard and quality control, making a percentage of 31.5 percent. 31 responses agreed with an 15.5 percent, while 61 responses disagreed with a percentage of 30.5 percent, while 81 respondents strongly disagreed that supervision in private basic schools are tailored to promote standard and quality control.

\subsection{Result of Findings}

Leaning on the responses and observations during the fieldwork, it is evident that there are 268 private basic schools distributed across the three Senatorial districts of Kano Central, Kano North and Kano South; comprising of 6 local government areas of Gwale, Fagge, Gwale, Dawaki, Wudil and Rogo. The result showed that Gwale and Fagge have the highest concentration of private basic schools with $118(44.02 \%)$ and $97(36.19 \%)$ respectively, while Gezawa has 22 (8.20\%), Dawaki 14 (5.22\%), Wudil 4 (1.19\%), Rogo 13 (4.85\%). The difference in the distribution is a reflection of the urban character of the areas surveyed. There are more number of immigrant population in Gwale and Fagge than the rest of the local government used in this study.

Research question 2 was aimed at finding out the most important factor responsible for private participation in the education sector. Majority of the respondents affirmed that recently people establish school with the intention of making abnormal profits. 43.5 percent of the respondents strongly affirmed this dispensation, while 37 percent agreed to it. 13 percent disagreed and 6.5 percent strongly disagreed. The respondents equally noted that other factors such as memorialization/immortalization of deceased relatives, job security, creation of job opportunities for the teeming unemployed youths and as an investment window are equally relevant, but only comes in as auxiliary factors.

On research question 3 which sort to interrogate the conduciveness of the environment in which the schools operate, there was a consensus among most of the respondents that the environment does not allow for pupils intellectual and cognitive development. 44.66 percent strongly condemns their environment while 34.66 percent disagreed that their environment is anything good. 8 percent and 12.66 percent strongly agreed and agreed respectively.

The next research question was tailored to find out if private basic schools are regularly supervised for standard and quality control. 13.5 percent and 15.5 percent strongly agree and agreed respectively that private 
basic schools in Kano state are regularly supervised to maintain standard and quality control. However, 30.5 percent and 40.5 disagreed and strongly disagreed respectively.

It was observed during the fieldwork that most of the schools visited are not better than public government schools. Significant number of them are located close to beer parlors and brothels that accommodate prostitutes. Many more operate in single room apartment partitioned to curve out smaller rooms and majority do not have enough playground for physical and health exercises.

\subsection{Conclusion}

Based on the findings of this research, it would not be out of place to conclude by saying that private basic schools and their proprietors have willingly abandoned the established parameters that would entrench high standard and ensure international best practices in the management of private schools in Kano and by extension in Nigeria. Evidence in most of the schools surveyed suggest that the complimentary functions which was the fulcrum for their admission into the education sector has been undermined for want of 'get rich quick syndrome' that regulates our attitudes. The result being that pupil's intellectual capabilities and cognitive development are greatly stultified. Standard and quality has been scarified on the alter of personal aggrandizement of the proprietors and the loquacious and predatory supervisory agencies who seeming compromised standard and high productivity for money and gratification.

\subsection{Recommendations}

Based on the research findings, the following recommendations are appropriate:

1) The present research work should serve as the foundation for proper documentation and registration of private schools all over Nigeria.

2) Through the TSA, all the proprietors should be compelled to pay appropriate tax to the government based on their sizes to prevent revenue leakages.

3) All the private schools operating in Kano should go back to the Ministry of Education for registration and revalidation of their license.

4) It is advised that a single supervisory agency be allowed to monitor and evaluate the performance of private schools in the states. The agency should establish offices in all the local government areas.

5) All private schools operating in the state must satisfy all the parameters for quality assurance before taking off. Those that could not meet up with acceptable standards should be sanctioned and closed down permanently.

6) Government should fix the minimum and maximum amount of fees to be collected by the owners of private schools in order to protect vulnerable guardians and parents from extortion. A taskforce should supervise this function.

\section{References}

Agi, M. K. (2013). Challenges and Prospects of Managing Private Schools System in Rivers State. African Research Review. An International Multidisciplinary Journal, Ethiopia, Vol. 7(1) Serial No. 28, 344-345.

Baikie, A. (2002). Recurrent Issues in Nigerian Education. Zaria: Tamaza Publishing Co. Ltd. 3-25.

Egwu, S. (2006).Roadmap for Nigerian Educational Sector.Federal Ministry of Education, Abuja, 21.

Ekundaro, T. A. (2005). "Repositioning Nigerian Educational System for Poverty Eradication". Education and Social Review (ESR) 2(1) 173-179.

Fadipe, J. O. (1999). "Quality Control in Education in Olagboye, A. A. and Fadipe, J. O. (eds), Management of Nigerian Education Law, Structures, Responsibilities, Ondo, NIEPA, 135-149.

Fafunwa, A. B. (1994). History of Education in Nigeria. London: George Allen and Unwin, 80-84.

Federal Ministry of Education, National Policy on Education. Federal Government Press, Abuja, 2004.

https://en.m.wikipedia.org.wikilistc.

Maduewesi, E. J. (2005). Benchmarks and Global Trends in Education. Benin Pasylvia Influences Enterprises, 203-204.

Odeleye, D.A., Oyelami (2012). Private Ownership and Educational Management in Nigeria: Issues and Challenges. Retrieved 28 January from www.transcampus.org/journals.

Olagbonye, A. A. (1997). Educational System Administration in Nigeria: Responsibilities and Practices. Lagos: Tison Press.

Omede, J. (2015), "Private Participation in Education: Issues that Matter". Asian Journal of Humanities and Social Sciences, Vol. 3 Issue 1, February.102-105.

Takena, K. (2016). Early Childhood Education and Its Influence on Academic Performance of Level One Pupils in Selected Primary Schools. Journal of Educational Policy and Entrepreneurship Research, Vol. 3, No. 7, July.P. 58. 